\title{
Effects of salinity and plasma prolactin on chloride cells in the gill of Chalcalburnus chalcoides
}

\author{
N Neuraste ${ }^{1}$, M Setorki $^{2}$, A Tehranifard ${ }^{1}$, A Moshfegh $^{1^{*}}$ \\ ${ }^{1}$ Department of Biology, Lahijan Branch, Islamic Azad University, Lahijan, Iran \\ ${ }^{2}$ Department of Biology, Izeh Branch, Islamic Azad University, Izeh,Iran
}

Received: February 2017

Accepted: July 2017

\begin{abstract}
Gill chloride cells and prolactin hormone are of Overall, these results suggest that $C$. chalcoides high importance in the adaptation of euryhaline fish. Guldenstati (Chalcalburnus chalcoides, 1772), an adromous fish, migrates from the Caspian Sea to rivers to have a more successful migration across its habitats is an energy consuming ecological behavior, and the fish consumes high energy just after breeding and while returning to the Caspian Sea.
\end{abstract} reproduction. The present study was aimed to evaluate the changes in the number and size of C. chalcoides gill chloride cells as well as to determine the relationship of its plasma prolactin with water salinity. Eighty-four individual $C$. chalcoides were collected from river (Lale Roud; 0.4 ppt), Lale Roud estuary (3.75 ppt), and Caspian Sea (9.71 ppt). The sampling was lasted for a-12 month period in 2014. The highest $(1349 \pm 152)$ and lowest $(881 \pm 37)$ number of gill chloride cells were observed in the animals collected from the Caspian Sea and in the river (Lale Roud), respectively. However, plasma prolactin demonstrated the highest level in $C$. chalcoides caught from the river $(0.89 \pm 0.02 \mathrm{ng}$ $\left.\mathrm{ml}^{-1}\right)$, but the lowest amount $\left(0.70 \pm 0.03 \mathrm{ng} \mathrm{ml}^{-1}\right)$ in the ones collected from the Caspian Sea.

Correspondence: A Moshfegh, Department of Biology, Lahijan Branch, Islamic Azad University, Lahijan, Iran (e-mail: moshfeghazam@gmail.Com).

Keywords: Salinity, Chloride cells, Prolactin, Chalcalburnus chalcoides

\section{Introduction}

Hydromineral regulation is of utmost importance in fish. Gills and gut, and particularly their chloride cells, are the main organs for regulation of water and ions in fish (Bradshaw and McCormick 2006). The concentration of the main blood plasma ions, especially $\mathrm{Na}^{+}, \mathrm{Cl}^{-}, \mathrm{Ca}^{2+}$, and $\mathrm{Mg}^{2+}$ readily reflects hydromineral regulation in fish. Plasma osmolarity in these animals living in freshwater is generally about 300 to $325 \mathrm{mOsmol} \mathrm{\textrm {L } ^ { - 1 }}$ and thus far above the ambient freshwater osmolarity, whereas in the seawater-dwelling fish it is about three times lower than seawater with 950 to $1050 \mathrm{mOsmol} \mathrm{L}^{-1}$ (Di Giulio and Hinton 2008). Hence, the osmotic and ion gradient across the branchial epithelia leads a 
driving force for passive water and ion movements between fish body and ambient water. The outflow of ions and osmotic uptake of water in freshwater fish as well as inflow of ions and osmotic water loss in seawater fish are effectively regulated via the integumental epithelia permeability to water and ions (Marshall and Grosell 2006). Due to their key function in ion transport activity, the gill chloride cells are characterized by an extremely well-developed endoplasmic canalicular system with the basolateral membrane and containing membrane-bound, ion-translocating enzymes such as $\mathrm{Na}^{+} / \mathrm{K}^{+}$- and $\mathrm{Ca}^{2+}$-ATPase which plays a crucial role in cells ion exchange, as well as different types of exchangers and postulated ion channels in the apical and basolateral membranes (Charoenphandhu, Limlomwongse and Krishnamra 2006).

Being hyperosmotic with respect to their environment, freshwater fish inevitably eliminate large volumes of diluted urine and retain salt (Bayly 1972). High urine flow rates following a high glomerular filtration rate and body osmolarity are controlled by a number of pituitary and non-pituitary hormones (such as prolactin, growth hormone, arginine vasotocin, angiotensin, and cortisol) controlling the organs involved in osmotic regulation to maintain the balance of hydro-minerals in different environments with different salinity (Haruta, Yamashita and Kawashima 1991, Mancera and McCormick 2007, Di Giulio and Hinton 2008).

Prolactin is an essential hormone to control hydro-mineral balance in freshwater fish. The main role of prolactin is epithelial permeability to ions and water, especially in gills, intestine and kidney epithelial tubes (Bonga 1997, Khalil, Hashem, Ibrahim and Mousa 2012). This hormone is of high important function in adaptation of euryhaline fish during migration from seawater to freshwater ecosystems (Manzon 2002). Guldenstati (Chalcalburnus chalcoides, 1772), an adromous fish, migrates to upstream and rivers to achieve more successful reproduction (Bagherian and Rahmani 2009, Coad 1996, Keivany, Nasri, Abbasi and Abdoli, 2016). C. chalcoideshas a high food value and economical position in the provinces surrounding the southern basin of the Caspian Sea. However, based on the reported information by International Union for Conservation of Natural Resources (IUCN), this fish species has been considered as vulnerable one (Kiabi, Abdoli and Naderi 1999). In spite of its valuable ecological and high economical position in the Caspian Sea and the provinces sounding the southern part of this lake, up to now, no study has been evaluated its gill infrastructural and blood hormonal changes during migration between freshwater and the Caspian Sea water. Hence, the present study was aimed to evaluate the changes in the number and size of $C$. chalcoides gill chloride cells as well as to determine the relationship of its plasma prolactin with water salinity in different salinities.

\section{Materials and Methods}

For this study, 84 healthy individuals of $C$. chalcoides (average total length: $16.5 \pm 4 \mathrm{~cm}$; average weight: $45.69 \pm 0.27 \mathrm{gr}$ ) were collected from three locations across its annual migration way (i.e., river, estuary, and Caspian Sea, with 
salinity of $0.4,3.75$, and $9.71 \mathrm{ppt}$, respectively). These locations are in the southern cost of the Caspian Sea and Lale Roud in Chamkhaleh, Guilan province (fig. 1). The sampling was lasted during a-12 month period in 2014; from the river, in May, June, July and August; from the estuary, in April and September; and from the sea, in October, November, December, January, February, and March. Some physicochemical parameters of water, including salinity, dissolved oxygen, $\mathrm{pH}$, and temperature, at the sampling sites are showed in Table 1.

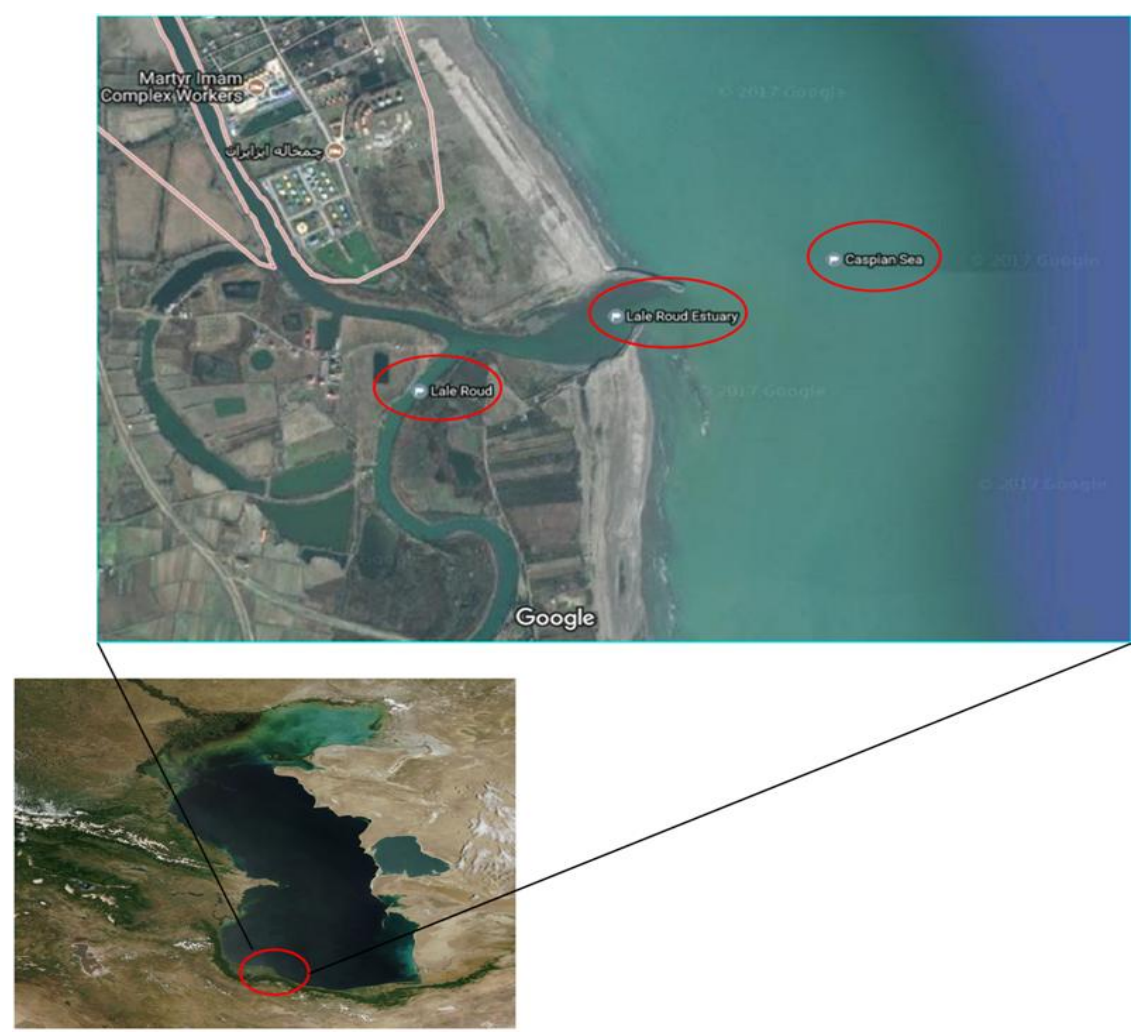

Figure 1.Sampling locations from the southern coast of the Caspian Sea, Chamkhale, Guilan, Iran.

Table 1. The mean value of air temperature as well as water physiochemical parameters at the sampling location in river (Lale Roud), estuary and the Caspian Sea

\begin{tabular}{ccccccc}
\hline \multirow{2}{*}{ Month } & $\begin{array}{c}\text { Sampling } \\
\text { environmental }\end{array}$ & $\begin{array}{c}\text { Air temperature } \\
\left({ }^{\circ} \mathrm{C}\right)\end{array}$ & $\begin{array}{c}\text { Water temperature } \\
\left({ }^{\circ} \mathrm{C}\right)\end{array}$ & $\begin{array}{c}\text { Dissolved } \\
\text { oxygen }\left(\mathrm{mg} 1^{-1}\right)\end{array}$ & $\mathrm{pH}$ & $\begin{array}{c}\text { Salinity } \\
(\mathrm{ppt})\end{array}$ \\
\cline { 3 - 7 } & & \multicolumn{2}{c}{ Mean $\pm \mathrm{SD}$} \\
\hline April & $\begin{array}{c}\text { Lale Roud } \\
\text { Estuary }\end{array}$ & $15.75 \pm 0.00$ & $13.61 \pm 0.00$ & $7.40 \pm 0.00$ & $8.10 \pm 0.00$ & 4.00 \\
\hline May & & $20.13 \pm 0.00$ & $19.08 \pm 0.00$ & $7.50 \pm 0.00$ & $8.30 \pm 0.00$ & 0.3 \\
Jun & River & $25.08 \pm 0.00$ & $24.48 \pm 0.00$ & $9.60 \pm 0.00$ & $8.40 \pm 0.00$ & 0.5 \\
Jul & & $26.02 \pm 0.00$ & $25.50 \pm 0.00$ & $9.20 \pm 0.00$ & $8.30 \pm 0.00$ & 0.4 \\
Aug & & $28.04 \pm 0.00$ & $27.39 \pm 0.00$ & $9.00 \pm 0.00$ & $8.20 \pm 0.00$ & 0.4 \\
\hline \multirow{2}{*}{ Sep } & Lale Roud & $26.16 \pm 0.00$ & $24.55 \pm 0.00$ & $8.10 \pm 0.00$ & $7.90 \pm 0.00$ & 3.50 \\
\hline Oct & Estuary & $22.49 \pm 0.00$ & $19.56 \pm 0.00$ & $9.00 \pm 0.00$ & $8.00 \pm 0.00$ & $9.50 \pm 0.00$ \\
Nov & & $19.28 \pm 0.00$ & $17.84 \pm 0.00$ & $8.10 \pm 0.00$ & $8.20 \pm 0.00$ & $10 \pm 0.00$ \\
Dec & Caspian Sea & $14.21 \pm 0.00$ & $11.78 \pm 0.00$ & $8.40 \pm 0.00$ & $8.00 \pm 0.00$ & $9.00 \pm 0.00$ \\
Jan & & $9.75 \pm 0.00$ & $9.00 \pm 0.00$ & $8.60 \pm 0.00$ & $8.00 \pm 0.00$ & $9.1 \pm 0.00$ \\
Feb & & $11.65 \pm 0.00$ & $10.27 \pm 0.00$ & $8.22 \pm 7.50$ & $8.20 \pm 0.00$ & $10.50 \pm 0.00$ \\
mar & & $12.41 \pm 0.00$ & $10.79 \pm 0.00$ & $8.20 \pm 0.00$ & $8.30 \pm 0.00$ & $10.20 \pm 0.00$ \\
\hline
\end{tabular}




\section{Blood plasma prolactin and gill chloride cellanalysis}

The collected fishes were anesthetized with clove extract (100 ppm), and their blood was obtained from the caudal vein using $5 \mathrm{cc}$ syringes. The blood samples were then transferred into heparinized tubes and centrifuged for 8 minutes at $4000 \mathrm{~g}$ to separate plasma. The plasma prolactin hormone measured according to the protocol described by Wheeler \&Hutchinson (2006). To determine the size and number of gill chloride cells, the fish gills were dissected and fixed in $10 \%$ formalin for 48 hours. After dehydration, clarification, and paraffin immersion, gill paraffin blocks were prepared, and then $5 \mu \mathrm{m}$ sections were prepared and stained with hematoxylin-eosin (H\&E). The number and size of chloride cells were observed using light microscopy and photographed.

\section{Statistical Analysis}

Data statistical analyses were conducted with SPSS software (SPSS, version. 22). All results are presented as the mean \pm standard deviation (S.D.). Significant differences were determined using one-way ANOVA, followed by Tukey test to compare the differences between the fish groups $(\mathrm{P}<0.05)$, and also the relationship between the number and size of chloride cells with plasma prolactin and water salinity were determined using Pearson correlation test $(\mathrm{P}<0.01)$.

\section{Results}

\section{Size and count of chloride cells}

Statistical analysis showed significant differences between the numbers of gill chloride cells in $C$. chalcoides in the three different water salinities ( $\mathrm{P}<0.05$, fig. $2 \mathrm{~A}$ ), with the highest (1349 \pm 152$)$ and lowest (881 \pm 37 ) number in the Caspian Sea and in the river (Lale Roud), respectively. Likewise, gill histological analysis demonstrated the same pattern forchloride cell size in the sampling environments, the largest and smallest in the highest (Caspian Sea) and lowest (Lale Roud) salinities, respectively (Tukey, $\mathrm{P}<0.05$; fig. $2 \mathrm{~B}$ and 3 ).

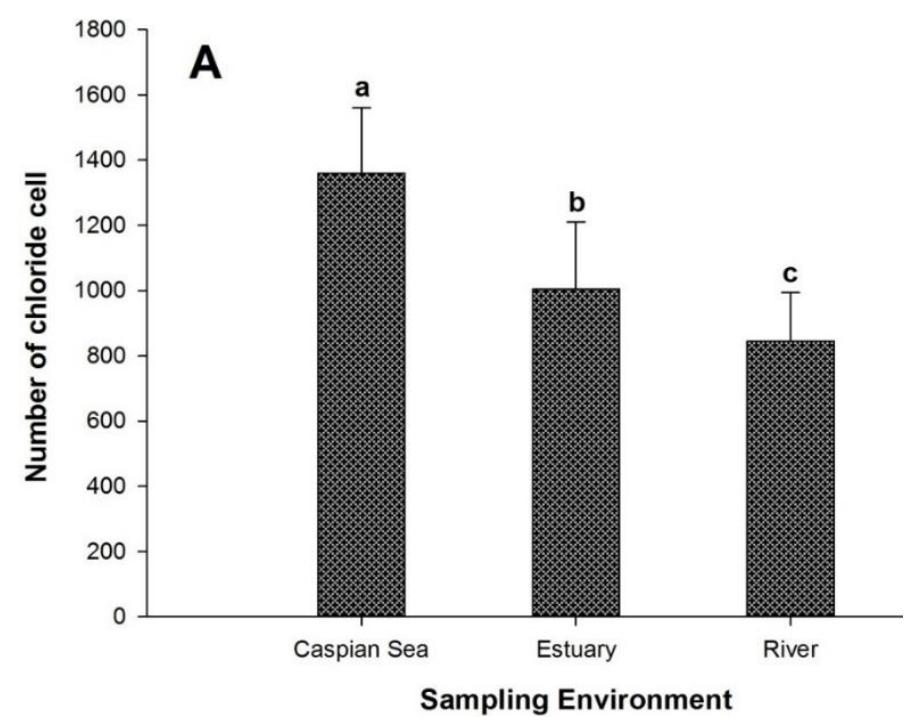




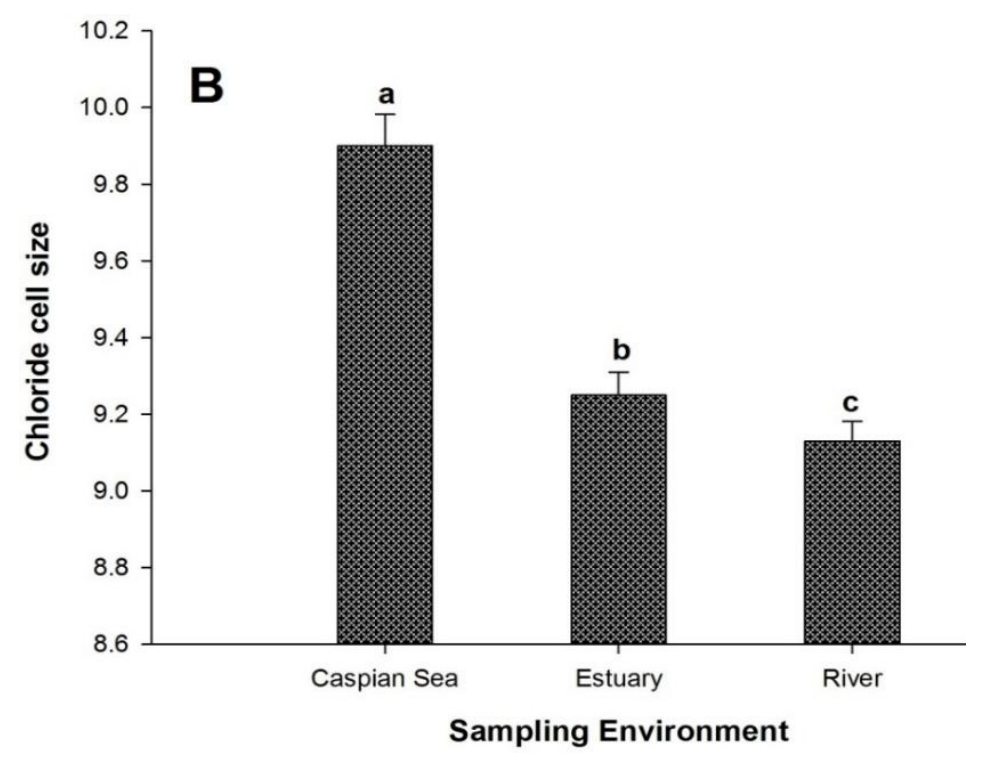

Figure 2. The average number (A) and size (B) of $C$. chalcoides gill chloride cells three different water salinities (Caspian Sea, estuary, and river). Different letters indicate statistically significant differences.

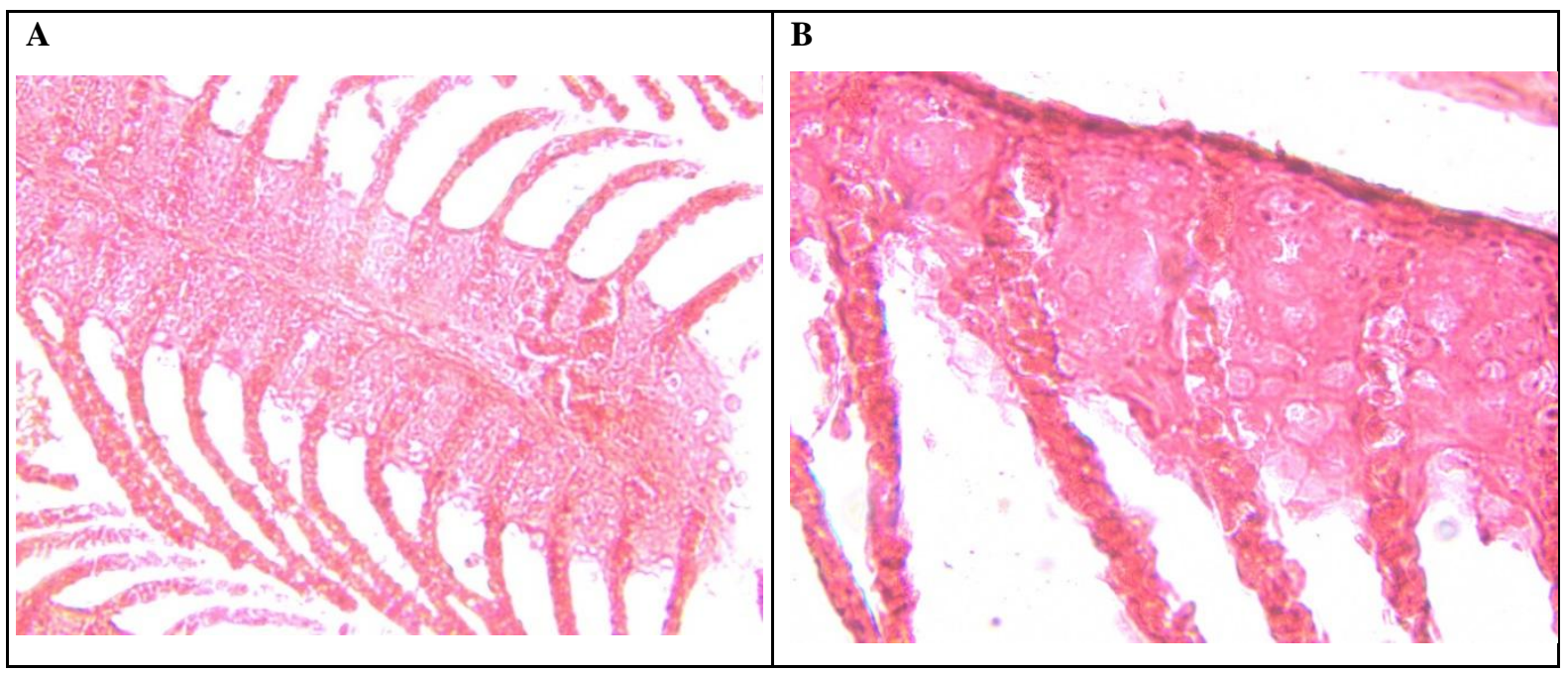

Figure 3. Histological sections of $C$. chalcoides gill caught from river (A)and (B) the Caspian Sea (x 40). H\&E staining.

\section{Plasma prolactin hormone}

The measurement of plasma prolactin showed the highest level in $C$. chalcoides caught from the river $\left(0.89 \pm 0.02 \mathrm{ng} \mathrm{ml}^{-1}\right)$, but the lowest amount $\left(0.70 \pm 0.03 \mathrm{ng} \mathrm{ml}^{-1}\right)$ in the ones collected from the Caspian Sea, i.e., the amount of prolactin hormone illustrated the highest and lowest concentrations in the 0.4 and $9.71 \mathrm{ppt}$, respectively (fig. 5; Tukey, $\mathrm{P}<0.05$ ). 


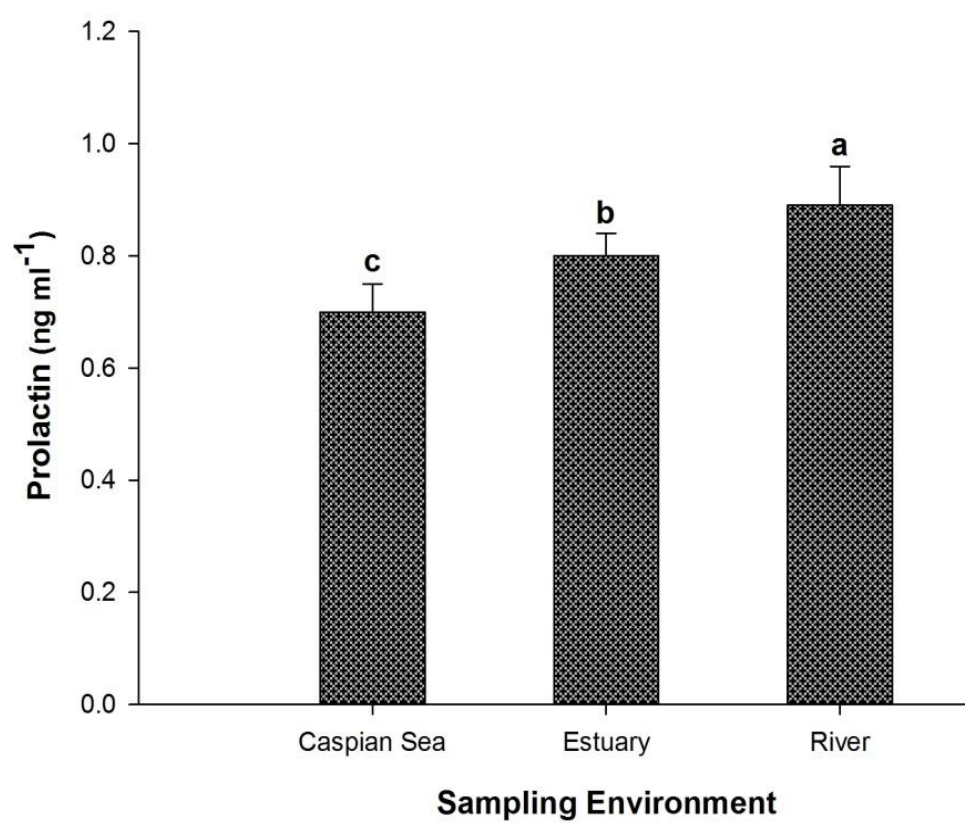

Figure 4. The mean values of plasma prolactin hormone of $C$. chalcoides in different sampling environments.

Different letters indicate statistically significant difference.

\section{Plasma prolactin hormone}

Table 2 illustrates correlation of both size and count of $C$. chalcoides gill chloride cells with plasma prolactin level and water salinity while migrating between ecosystems with different salinities. Pearson correlation demonstrated a strong positive correlation between the number and size of chloride cells with water salinity, yet a significant negative correlation with plasma prolactin level. In addition, with increase of water salinity a remarkable negative correlation was observed.

Table 2. Correlation of size and count of $C$. chalcoides gill chloride cells with plasma prolactin level and water salinity (Pearson correlation)

\begin{tabular}{lccc}
\hline & number of chloride cells & size of chloride cells & Prolactin \\
\hline Size of chloride cell & $0.90^{* *}$ & & \\
\hline Prolactin & $-0.84^{* *}$ & $-0.93^{* *}$ & \\
Salinity & $0.90^{* *}$ & $0.98^{* *}$ & $-0.94^{* *}$ \\
\hline
\end{tabular}

** Asterisks show significant correlation and (-) shows negative correlation.

\section{Discussion}

Fish gill is considered as the main organ involved in the osmoregulation and maintaining the hydro-mineral balance in hyperosmotic and hyposmotic environments. In some fishes, gill chloride cells have been infrastructurally adapted to fish homeostasis within different 
water salinities; that is, these cells (especially in gills) vitally maintain a biologically suitable hydro-mineral balance between the external and internal body environment following alterations in their size, count, and surface area (Katoh, Hyodo and Kaneko 2003, Laiz-Carrión, Guerreiro, Fuentes, Canario, Martín Del Río and Mancera 2005). Chloride cells have some special structural characteristics such as numerous mitochondria, wide cytoplasmic, and special enzymatic systems of $\mathrm{Na}^{+} / \mathrm{K}^{+}$ATPase (Uchida and Kaneko 1996). These unique structural and functional features allow the removal of large volume of monovalent ions against concentration gradient in salt water (Pourkhadje, Abdi, Zolgharnein, Hoseinzade Sahaf and Morovvati 2015). The present study evaluated changes in size and count of gill chloride cells as well as fluctuations in plasma prolactin hormone in $C$. chalcoides, a fish seasonally migrating between river and the Caspian Sea,while migrating between its different seasonal habitats (i.e., rive, estuary, and Caspian Sea). The results demonstrated a significant increase in the chloride cell count when the fish migrate from freshwater (river) to a higher water salinity (Caspian Sea), and also the same pattern was hold true for their size. The highest average count of gill chloride cells was observedin the fish collected from the habitat with the highest salinity (1349 \pm 152$)$, whereas it was the lowest in the freshwater habitat $(881 \pm 37)$.

To migrate from environments with low salinity or electrolyte, fish need a significant increase in the number of ion carriers in the cell membrane and thus higher enzymatic activities contributed to maintain internal water and electrolyte homeostasis. Therefore, they require increasing the chloride cells for which they are specialized (Zydlewski and McCormick 2001). Hence, the observed alteration in the gill chloride cell count and size can be an adapting physiological phenomenon needed during migration from the hyperosmotic to hyposmotic environments. These data are consistent with that observed studiesin which the migration andosmoregulation of some anadromous and catadromous fish species such as, Oreochromis mossambicus (Uchida, Kaneko, Miyazaki, Hasegawa and Hirano 2000), Oncorhynchus keta (Uchida and Kaneko 1996), Rutilus frisii kutum (Ataimehr, Mojazi, Mirvaghefi, Nezami and Riazi 2010), Acipenser persicus (Jabbarzadeh, Abtahi, Mojazi and Nazari 2000), Cyprinodon variegatus (Karnaky, Ernst and Philpott 1976), Epinephelus coioides (Pourkhadje et al. 2015), Chalcalburnus tarichi (Oğuz 2013), Barbus sharpeyi (Koohkan 2017) and Cyprinus carpio (Azizi, Kochanian, Peyghan, Khansari and Bastami 2011)were evaluated.

Plasma prolactin level significantly elevated following reduction in water salinity from the Caspian Sea to Lale Roud. Likewise, Pearson correlation test showed a strong inverse correlation between the amount of prolactin hormone with the size and number of gill chloride cells between the fish caught from different salinities; i.e., the higher water salinity and the more size and count of gill chloride cells, the lower amount of plasma prolactin hormone was observed. These results are in 
accord withstudy conducted by Prunet et al (1985) in which Salmo gairdneri was transferred from seawater to freshwater, and a significant elevationwas observed in plasma prolactin. Further, daily injections of ovine prolactin into Oreochromis mossambicus at a dose of $10 \mu \mathrm{g} \mathrm{g}^{-1}$ caused a significant reduction in the size of chloride cells (Herndon, McCormick and Bern 1991). During the adaptation of euryhaline fish to different salinities, particularly when migrating from saltwater to freshwater, the number and size of chloride cells obviously decrease and, even in some species, these cells are completely destroyed by plasma prolactin hormone; that is, the main role of prolactin in all euryhaline fish is the controlling of water and sodium transfer across the gill epithelium, especially during the migration from sea water to fresh water (Prunet, Boeuf and Houdebine 1985).

\section{Conclusions}

The present results, therefore, clearly suggested that $C$. chalcoides migration across its habitats is an energy consuming ecological behavior, and this fish consumes high energy just after breeding and while returning to the Caspian Sea.In addition, water salinity and prolactin hormone can play essential functions in the morphology and distribution of chloride cells.

\section{Acknowledgment}

The authors would like to acknowledge the Islamic Azad University of Lahijan for supplying the sampling facilities and for helping during the experimental procedures.

\section{References}

Ataimehr, B., Mojazi, A.B., Mirvaghefi, A., Nezami, S. \& Riazi, G. (2010) Effect of different salinity on ions, osmolarity, water concentration of body tissue, gill chloride cells and mortality percentage of juveniles of Caspian roach (Rutilus frisii kutum Kamensky, 1901). Iranian Scientific Fisheries Journal, 19, 115 - 130. (In Persian).

Azizi, S., Kochanian, P., Peyghan, R., Khansari, A. \& Bastami, K.D. (2011) Chloride cell morphometrics of common carp, Cyprinus carpio, in response to different salinities. Comparative Clinical Pathology, 20, 363-367.

Bagherian, A. \& Rahmani, H. (2009) Morphological discrimination between two populations of shemaya, Chalcalburnus chalcoides (Actinopterygii, Cyprinidae), using a truss network. Animal Biodiversity and Conservation, 32, 1-8.

Bayly, I. (1972) Salinity tolerance and osmotic behavior of animals in athalassic saline and marine hypersaline waters. Annual review of ecology and systematics, 3, 233-268.

Bonga, S.W. (1997) The stress response in fish. Physiological reviews, 77, 591-625.

Bradshaw, D. \& Mccormick, S. (2006) Hormonal control of salt and water balance in vertebrates-A symposium. In. Academic Press.

Charoenphandhu, N., Limlomwongse, L. \& Krishnamra, N. (2006) Prolactin directly enhanced $\mathrm{Na}^{+} / \mathrm{K}^{+}$-and $\mathrm{Ca}^{2+}$ - ATPase activities in the duodenum of female rats. Canadian 
journal of physiology and pharmacology, 84, 555-563.

Coad, B.W. (1996) Systematics of the shah mahi, Chalcalburnus chalcoides (Güldenstädt, 1772), in the southern Caspian Sea basin (Actinopterygii: Cyprinidae). Zoology in the Middle East, 12, 65-70.

Di Giulio, R.T. \& Hinton, D.E. (2008) The toxicology of fishes, Crc Press.

Haruta, K., Yamashita, T. \& Kawashima, S. (1991) Changes in arginine vasotocin content in the pituitary of the medaka (Oryzia latipes) during osmotic stress. General and comparative endocrinology, 83, 327-336.

Herndon, T.M., Mccormick, S.D. \& Bern, H.A. (1991) Effects of prolactin on chloride cells in opercular membrane of seawater-adapted tilapia. General and comparative endocrinology, 83, 283-289.

Jabbarzadeh, S., Abtahi, B., Mojazi, B. \& Nazari, R. (2000) Study on the changes of some physiological factors during osmoregulation of juvenile Persian sturgeons (Acipenser persicus). Iranian Journal Of Fisheries Sciences, 3, 55-63. (In Persian).

Karnaky, K.J., Ernst, S.A. \& Philpott, C.W. (1976) Teleost chloride cell. I. Response of pupfish Cyprinodon variegatus gill $\mathrm{Na}, \mathrm{K}-$ ATPase and chloride cell fine structure to various high salinity environments. The Journal of cell biology, 70, 144-156.
Katoh, F., Hyodo, S. \& Kaneko, T. (2003) Vacuolar-type proton pump in the basolateral plasma membrane energizes ion uptake in branchial mitochondria-rich cells of killi fish Fundulus heteroclitus, adapted to a low ion environment. Journal of Experimental Biology, 206, 793-803.

Keivany, Y., Nasri, M., Abbasi, K., Abdoli, A. (2016) Atlas of inland water fishes of Iran. Iran Department of Environment Press. 218 p. (In Persian).

Khalil, N.A., Hashem, A.M., Ibrahim, A.A. \& Mousa, M.A. (2012) Effect of Stress During Handling, Seawater Acclimation, Confinement, and Induced Spawning on Plasma Ion Levels and Somatolactin-Expressing Cells in Mature Female Liza ramada. Journal of Experimental Zoology Part A: Ecological Genetics and Physiology, 317, 410-424.

Kiabi, B.H., Abdoli, A. \& Naderi, M. (1999) Status of the fish fauna in the South Caspian Basin of Iran. Zoology in the Middle East, 18, $57-65$

Koohkan, O. (2017) Effects of different levels of salinity on number and size of chloride cells in gill of Benny fingerling (Barbuss harpeyi). Journal of Comparative Pathobiology, 14.

Laiz-Carrión, R., Guerreiro, P.M., Fuentes, J., Canario, A.V., Martín Del Río, M.P. \& Mancera, J.M. (2005) Branchial osmoregulatory response to salinity in the gilthead sea bream, Sparus auratus. Journal of 
Experimental Zoology Part A: Ecological Genetics and Physiology, 303, 563-576.

Mancera, J.M. \& Mccormick, S.D. (2007) Role of prolactin, growth hormone, insulin-like growth factor $I$ and cortisol in teleost osmoregulation. Fish Osmoregulation, 497515.

Manzon, L.A. (2002) The role of prolactin in fish osmoregulation: a review. General and comparative endocrinology, 125, 291-310.

Marshall, W. \& Grosell, M. (2006) Ion transport, osmoregulation, and acid-base balance. The physiology of fishes,3, 177-230.

Oğuz, A.R. (2013) Environmental regulation of mitochondria-rich cells in Chalcalburnus tarichi (Pallas, 1811) during reproductive migration. Journal of Membrane Biology, 1-6.

Pourkhadje, M., Abdi, R., Zolgharnein, H., Hoseinzade Sahaf, H. \& Morovvati, H. (2015) Effects of different salinity on number and area of chloride cells in gill of juvenile grouper (Epinephelus coioides). Iranian Scientific Fisheries Journal, 23, 1-10. (In Persian).
Prunet, P., Boeuf, G. \& Houdebine, L. (1985) Plasma and pituitary prolactin levels in rainbow trout during adaptation to different salinities. Journal of Experimental Zoology Part A: Ecological Genetics and Physiology, 235, 187196.

Uchida, K. \& Kaneko, T. (1996) Enhanced chloride cell turnover in the gills of chum salmon fry in seawater. Zoological science, 13, 655-660.

Uchida, K., Kaneko, T., Miyazaki, H., Hasegawa, S. \& Hirano, T. (2000) Excellent salinity tolerance of Mozambique tilapia (Oreochromis mossambicus): elevated chloride cell activity in the branchial and opercular epithelia of the fish adapted to concentrated seawater. Zoological science, 17, 149-160.

Wheeler, M.J. \& Hutchinson, J.M. (2006) Hormone assays in biological fluids, Springer.

Zydlewski, J. \& Mccormick, S.D. (2001) Developmental and environmental regulation of chloride cells in young American shad, Alosa sapidissima. Journal of Experimental Zoology Part A: Ecological Genetics and Physiology, 290, 73-87. 
تأثير شورى آب و يرولاكتين «يلاسما بر سلولهاى كلرايد آبشش ماهى شاه كولى (Chalcalburnus chalcoides)

\author{
نعَار نورسته'، محبوبه ستر كى '، اكرم تهرانى فرد'، اعظم مشفق ا"* \\ ا كروه زيست شناسى، واحد لاهيجان، دانشخاه آزاد اسلامى، لاهيجان، ايران \\ r بروه زيست شناسى، واحد ايذه، دانشعاه آزاد اسلامى، ايذه، ايران
}

جكيده

سلولهاى كلرايد آبشش و هورمون يرولاكتين اهميت بسزايى در سازكار شدن ماهيان يورى هالين دارند. ماهى شاه كولى بهعنوان يكى ماهى آنادروموس، از درياى خزر بلمنظور داشتن تكثير موفقتر به رودخانهها مهاجرت مى كند. مطالعه حاضر جهت بررسى تغيير در تعداد و اندازه سلولهاى كلرايد آبشش و همجنين تعيين ارتباط ميان يرولاكتين پلاسماى خون ماهى شاه

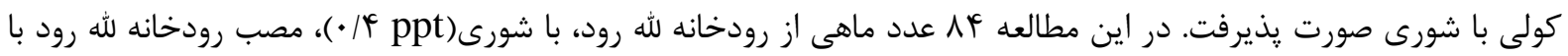

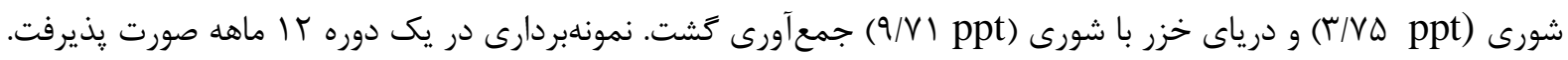

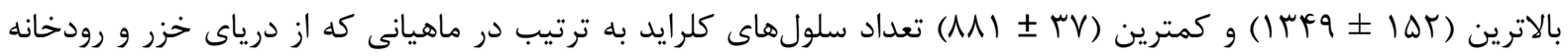

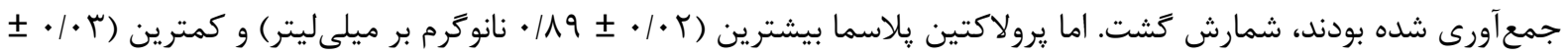
• • • •انوگرم بر ميلىليتر) ميزان را در ماهيانى نشان داد كه به ترتيب از رودخانه و درياى خزر صيد شده بودند. بطور كلى، نتايج بيانكر اين است كه مهاجرت ماهى شاه كولى در بين زيستخاههاى آن، يك رفتار اكولوزيك با مصرف بالاى انرزى همراه است و اين ماهى دقيقاً بعد از تخمريزى و هنكام بر گشتن به درياى خزر ميزان بالايى انرزى مصرف مى كند.

كلمات كليدى: شورى، سلولهاى كلرايد، يرولاكتين، ماهى شاه كولى.

"نويسنده مسئول: moshfeghazam@gmail.Com 